Hydroécol. Appl. (1991) 1, pp. $127-145$

\title{
Spatial distribution of aquatic macrophytes in the recent reservoir of Ste Croix, Provence, France.
}

\author{
A. Vaquer $^{(1)} \&$ A. Champeau $(2)$ \\ (1) Laboratoire d'Hydrobiologie Marine et Continentale, URA 1355-CNRS, Université de Mont- \\ pellier II, Place E. Bataillon, F-34095 Montpellier Cedex 5. \\ (2) Laboratoire d'hydrobiologie. Université de Provence, 3, place Victor Hugo - $13331 \mathrm{Mar}$ - \\ seille Cedex 3.
}

\begin{abstract}
Investigations on horizontal and vertical distribution of aquatic vegetation have been carried out in the regulated lake Sainte Croix from 1985 to 1987 . This reservoir, being filled in 1974, has been recently colonized by submersed vegetation. Macrophyle data have been collected by using direct observations, echosoundings and grapnel sampling. Two remarkable macroalgae (Tolypella glomerata, Charophyta from temporary water bodies with high alkalinity, and Vaucheria nicholsii, Xanthophyta less known in Europe) and six cosmopolitan phanerogams typical of alkaline waters were recorded in the littoral zone, especially in the bays of Bauduen, Les Salles and Moustiers. Macroalgae reached a maximum growth during spring. Phanerogams developed the most in summer. Myriophyllum spicatum was the dominant species in the whole lake, being associated with Potamogeton crispus in the bay of Moustiers and $P$. nodosus in the bays of Les Salles and Bauduen. Macrophyte depth ranged from 1.9 to $11.3 \mathrm{~m}$. Mean depth was $4.4 \mathrm{~m}$ for all the species, varying from $3.5 \mathrm{~m}$ (Potamogeton pusillus) to $5.5 \mathrm{~m}$ ( $V$. nicho/sii). The capacity of several predictive models to predict the depth distribution of macrophytes in relation to transparency (Secchi disc) and water level fluctuations is discussed. The best estimation occurs with a model based on mean annual regulation level. Some other environmental parametres, such as nutrient-rich inflows, particularly from sewage supplies, may explain the clustered vegetation communities in some localized stations.
\end{abstract}

Keywords: Macrophytes, hydroelectric reservoir, spatial distribution, transparency, water-level fluctuations, sewage effluents. 


\section{INTRODUCTION}

The aquatic vegetation seems to be more and more significant in regard to the aquatic escosystem functioning by interacting with phytoplankton (Balls and al., 1985), nutrients (Riber, 1984; Anderson \& Kalff, 1986; Nutall, 1985) and sediments (Smith \& Adams, 1986). The specific structure of the macrovegetation and its evolution may indicate the trophic level of the aquatic environments (Lachavanne \& Wattenhofer, 1975; Burgermeister \& Lachavanne, 1980; Downing \& Anderson, 1985; Ravera and al., 1984) or the course of eutrophication (Ozimek \& Kowalczewski, 1984; Best et al., 1984). The macrophyte developement can be related to nutrient load, mainly P-load and at this time it is considered either as a nuisance (Schloesser \& Manny, 1984 ) or as a sewage clarifier (Galanti and al, 1985; Blake \& Dubois, 1982). This submersed vegetation can also perform a significant part in fish community dynamic as props for reproduction (Gillet, 1985), food and shelter.

The present study carried out in 1985 and 1986 is a first evaluation of the aquatic vegetation of Lake Sainte Croix (Provence, France) following a recent colonization. It includes a floristic list and a map of the different observed species. Spatial distribution of the macrophytes is discussed according to some environmental factors. Lake Sainte Croix was completely filled up in 1974. No vegetation was observed before 1980 .
The first large macrophyte communities were observed during 1982 and 1983 (Bressac \& Champeau, 1985; Chappaz and al., 1985). The reservoir is destined at first for hydroelectric production. Elsewhere, it is destined for drinking water and leisure activities (tourism, fishing).

This work is a part of a general research program on the functioning of Lake Ste Croix, one of the five sites studied by Greco 71 (CNRS) ${ }^{3}$ "Fonctionnement des écosystèmes lacustres».

\section{I. - MATERIAL AND METHODS}

\section{1 - Study site}

Lake Ste Croix (48.7 latitude $\mathrm{N}$ and $4.3^{\circ}$ longitude $\mathrm{E}$ ) is located on the River Verdon, at an altitude of $477 \mathrm{~m}$ (normal retention level), downstream from the Castillon and La Chaudanne Reservoirs and above the Quinson and Greoux Reservoirs (figure 1). This reservoir is the most recent one among this fitting out succession and its construction was finished in 1974.

Since, the main characteristics concerning the catchment area, the water quality and the biological factors of the lake have been given by Gregoire (1982), Champeau and al. (1982), Bressac \& Champeau (1985). The lake is $11 \mathrm{kms}$ long and $2 \mathrm{kms}$

3 Groupement de Recherches Coordonnées (Centre National de la Recherche Scientifique). 


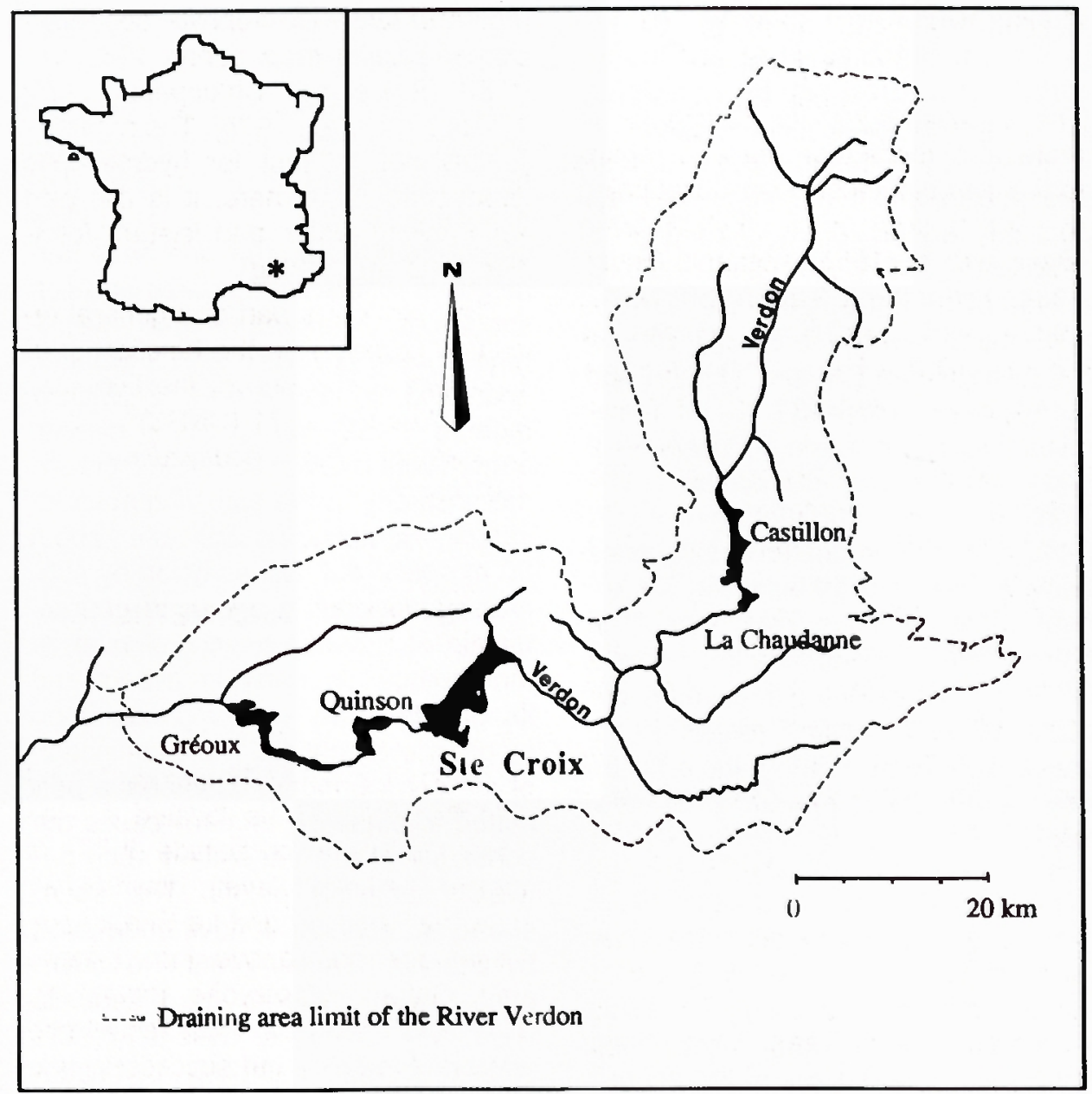

Fig. 1. - Location of Lake Sainte Croix on the River Verdon.

wide. Its mean depth is $50 \mathrm{~m}$ (maximum $83 \mathrm{~m}$, near the dam). Water replacement is 280 days long. The reservoir exploitation for electric production leads to annual water level fluctuations («marling») over a range of several metres. The maximum fluctuation of $16 \mathrm{~m}$ was reached in January of 1986.
Lake Ste Croix is a warm monomictic type lake. Water temperature at $1 \mathrm{~m}$ depth ranges from $6^{\circ} \mathrm{C}$ in winter to $26^{\circ} \mathrm{C}$ in summer. The maximum depth of the thermocline is between 15 and $20 \mathrm{~m}$. Water conductivity (mean $300 \mu \mathrm{S} . \mathrm{cm}$ ) indicates a quite high mineralisation level owing to abundant carbonates which lead to an 
alkaline water ( $\mathrm{pH}$ near 8). As regards the nutrients level and transparency, Ste Croix can be considered as a mesotrophic lake (Vaquer \& El Hafa, 1991). Mean values for total phosphorus and total nitrogen are respectively about 20 and $230 \mu \mathrm{g} / \mathrm{h}$ in 1985 and 1986 . Water lake is characterised by a low transparency : the annual mean depth of Secchi disc is $5.4 \mathrm{~m}$ (between 2.3 and $11.4 \mathrm{~m}$ ) and corresponds with $18.9 \%$ of transmitted light (on average, between 2 and $45 \%$ ). Mean attenuation coefficient $(\mathrm{Kd})$ of downwelling light is $0.32 \mathrm{~m}^{-1}$ and euphotic depth varies between 9.8 and $19 \mathrm{~m}$ along an annual cycle. In contrast the low chlorophyll-a concentration levels $\left(-1 \mathrm{mg} \mathrm{m}^{-3}\right)$ and the maximum primary production rates (between 1.2 and $2 \mathrm{mg} \mathrm{C} \mathrm{m} \mathrm{m}^{-3} \mathrm{~h}^{-1}$ ) indicate an oligotrophic status (Vaquer \& El Hafa, 1991).

\section{2 - Methods}

Map-drawing was taken down during 1985. A general survey of the aquatic vegetation was made all around the lake. The three main bays being located near by the Bauduen, les Salles and Moustiers villages were more accurately studied (figure 2). The depths of the observations and samplings have been referred to the normal retention level.

Submersed vegetation maps were established according to transects being carried out over the bays and determined according to easy land- marks in situ which equally appeared on geographic map.

Depth and bottom aspects are continuously recorded along the transects by a graphical echosounder (Lowrance $\times 15 \mathrm{MA}$ ). Echosounding charts from the bottom line have permitted to differentiate coarse and soft substrates. At the same time, macrophytes were collected with a grapnel, according to Schloesser \& Manny method (1982; 1984). Every minute, a mark was made on chart to increase the accuracy of the sampling point location. Sampling points are about $30 \mathrm{~m}$ space out. Echos given by submersed vegetation are quite characteristic of a species, according to its morphology, its carrying aspect and its growth form, as being confirmed by grapnel sampling. The examination of the echosounding charts have permitted to establish in many cases the continuity of the vegetation mats between sampling points. The echosounding techniques have been used by Stent \& Hanley (1985) to determine plant heights and aquatic vegetation biomass. Duarte (1987) considers that sampling by echosounding is as accurate as by diving.

Sampling characteristics are reported for each bay in table 1. Knowing the transducer transmitting angle $\left(a=8^{\circ}\right)$, the observed bottom area of each transect $S$ is determined as : $S=L . z \cdot \operatorname{tg}(a)$, where $L=$ transect length and $z=$ mean depth of transect. The prospected areas account on average for $2.3 \%$ of the total areas of the three bays. This percentage is similar to those determined in different 


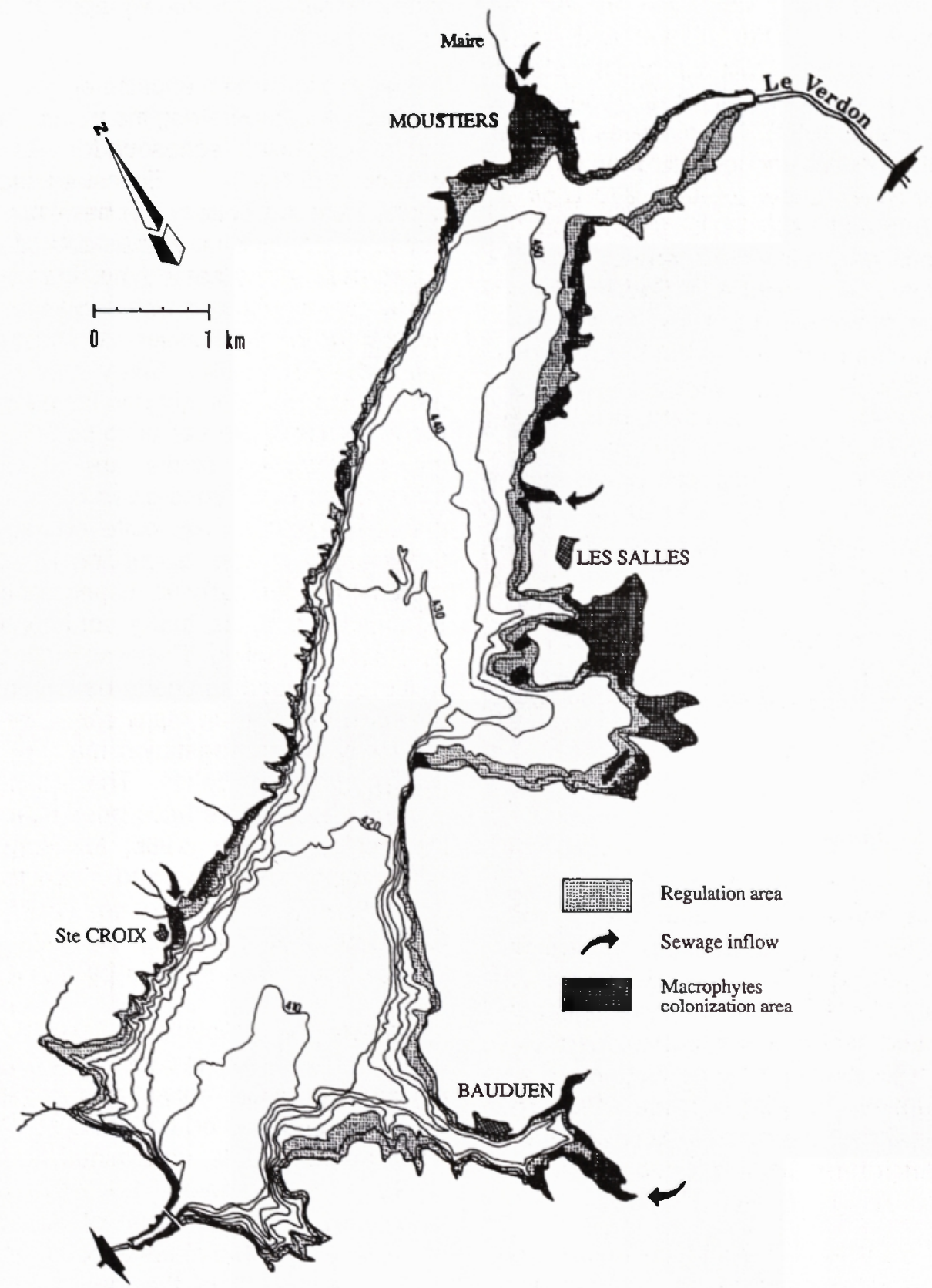

Fig. 2. - Bathymetry, maximum extent of marling and macrophyte colonization areas in Lake Sainte Croix in 1985. 
A. Vaquer et A. Champeau

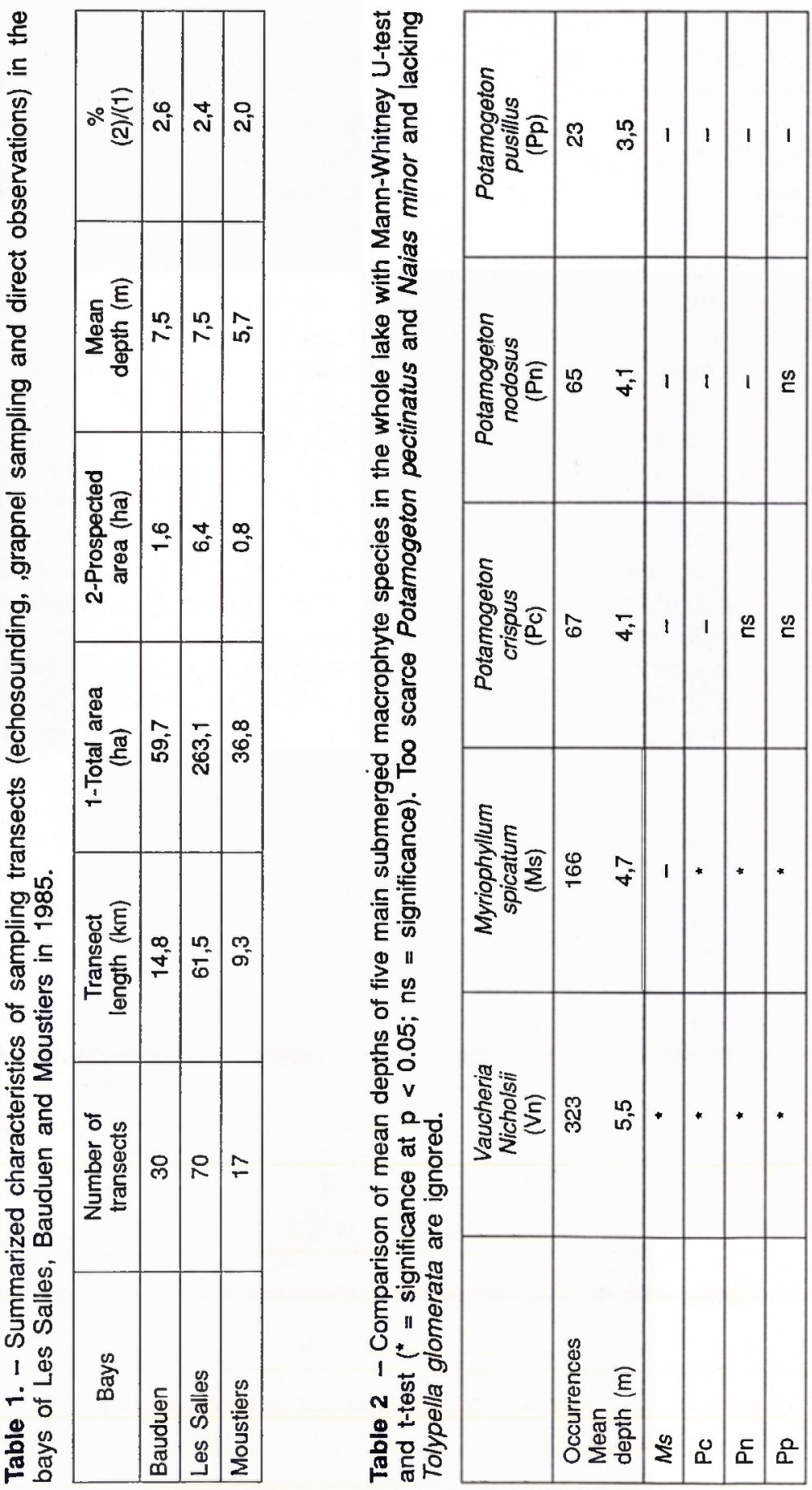


studies by using other methods as direct observations or diving stereophotographies on covered areas (Dubois and al., 1984; Carpenter \& Titus, 1985; Rørslett, 1985), or Bernatowicz sampler (Ozimek \& Kowalczewski, 1984).

The observations (echosoundings and grapnel samplings) were made from $25 / 07 / 85$ to $5 / 09 / 85$. The maps were complemented by direct observations from the surface in the shallowest areas and by diving in the deepest zones. During the wintry "marling" of 1986, the littoral area and particularly the bays were quite completely out of water and have been visited on foot. So, the extent of the macrophyte patches and the distribution of the more littoral plants which were not always taken in account in the transects have been more accurately defined. At the same time, substrate samples were directly observed to make clear the bottom type being colonised by each species.

Statistical calculations are based on the species occurrence which corresponds with its presence being associated with its depth in a sampling point.

\section{II. - RESULTS}

Macrophytes were only present in some shallow littoral areas of Lake Ste Croix because of the very hilly relief and the large range of water regulation of this hydroelectric reservoir. The macrophyte list consists essentially of two macroalgae, Tolypella glomerata (Desv. in Lois.) Leonhardi (Charophycea) and Vaucheria nicholsii Brown (Xanthophycea) and six phanerogams, Potamogeton pectinatus L., P. crispus L., P. nodosus Poir., P. pusillus L., Myriophyllum spicatum L. and Naias minor All.

The Potamogeton species are usually recorded in alkaline sites (Hellquist, 1980; Kadono, 1982). $P$. pectinatus and $M$. spicatum grew generally in very alkaline waters (Nichols \& Shaw, 1986). Recorded macroalgae are less well known, particularly $V$. nicholsii which has been very rarely observed on the European continent and T. glomerata which is practically unknown in lacustrine sites in spite of its wide distribution because of its large salinity tolerance. Both these algae can develop very thick and continuous mats in Lake Ste Croix.

Tolypella glomerata and Vaucheria nicholsii showed their maximal development during spring (March, April). At the end of June, T. glomerata was almost completely degenerated. Vaucheria was present during the whole year but was in resting phase from summer to winter. The maximum development of the most phanerogams was generally observed during summer. A few mats of the alga Spirogyra were also observed, always in a scarce extent (up to about some hundred $\mathrm{m}^{2}$ ).

\section{1 - Horizontal distribution}

Large macrophyte communities were essentially growing in the bays of 
Moustiers, Les Salles and Bauduen and also on a shoal near the Ste Croix village. Scattered macrophyte patches are also observed all around the littoral zone, except in the more downstream part of the lake near the dam where banks are too sloping (figure 2). The species distribution in each bay is presented on figure 3 to 5 . Calculation on species occurrences (obtained by echosounding and grapnel sampling) bring accuracy to the whole observations. T. glomerata is not taken in account in this calculation because of its lacking in the summer transects.

T. glomerata covered an important area in the bay of Les Salles as well on coarse substrates (silt and pebbles) in the upper part of the littoral area, as on slime in its lower part. In the bay of Bauduen, only some very punctual mats of Tolypella were detected.

V. nicholsii covered almost all the slimy substrates in the bay of Les Salles and, in a lesser extent, in the bay of Bauduen. Its relative occurrence represents respectively $56.3 \%$ and $47.5 \%$ in each bay. Elsewhere both these algae were almost lacking around the lake.

N. minor, scarce in the bay of Les Salles and the bay of Bauduen, was the more littoral among the species encountered in Lake Ste Croix : it was growing in the shallowest area, yields to wave beats and continuous water level fluctuations (figure 3).

Myriophyllum spicatum was the dominant phanerogam with represented respectively $55.9 \%, 16,6 \%$ and $41 \%$ of the total occurrences of the macrophytes in the three bays. It was found on every substrate type and even being fixed by its rhizoms in rock cracks in the bay of Les Salles.

P. pusillus was only present in the slopeless part of the bay of Les Salles being characterized by little tufts on mixed silt and pebble substrates (figure 4).

P. crispus was the second phanerogam species occurring in the whole lake and represented respectively $41.2 \%, 8.3 \%, 1.6 \%$ of the total occurrences of the macrophytes in the bays of Moustiers, Les Salles and Bauduen. This macrophyte formed scarce small patches (1 to 2 metres wide) near the outflow of a sewage treatment station in the bay of Bauduen and a practically continuous mat in the bay of Moustiers.

$P$. nodosus was the second abundant species in the bays of Bauduen and Les Salles where it represented respectively $9 / .8 \%$ and $11.3 \%$ of the phanerogam occurrences. It was totally lacking at Moustiers. It formed more or less wide patches on every substrate without pebble. Its broad ending leaves floated on the water surface. At the end of July blossoming and fruit bearing were observed.

$P$. pectinatus (figure 5) was not abundant and formed small solitary patches. Leafy ends of thick plants floated on the water surface and darkened almost completely the water column. 


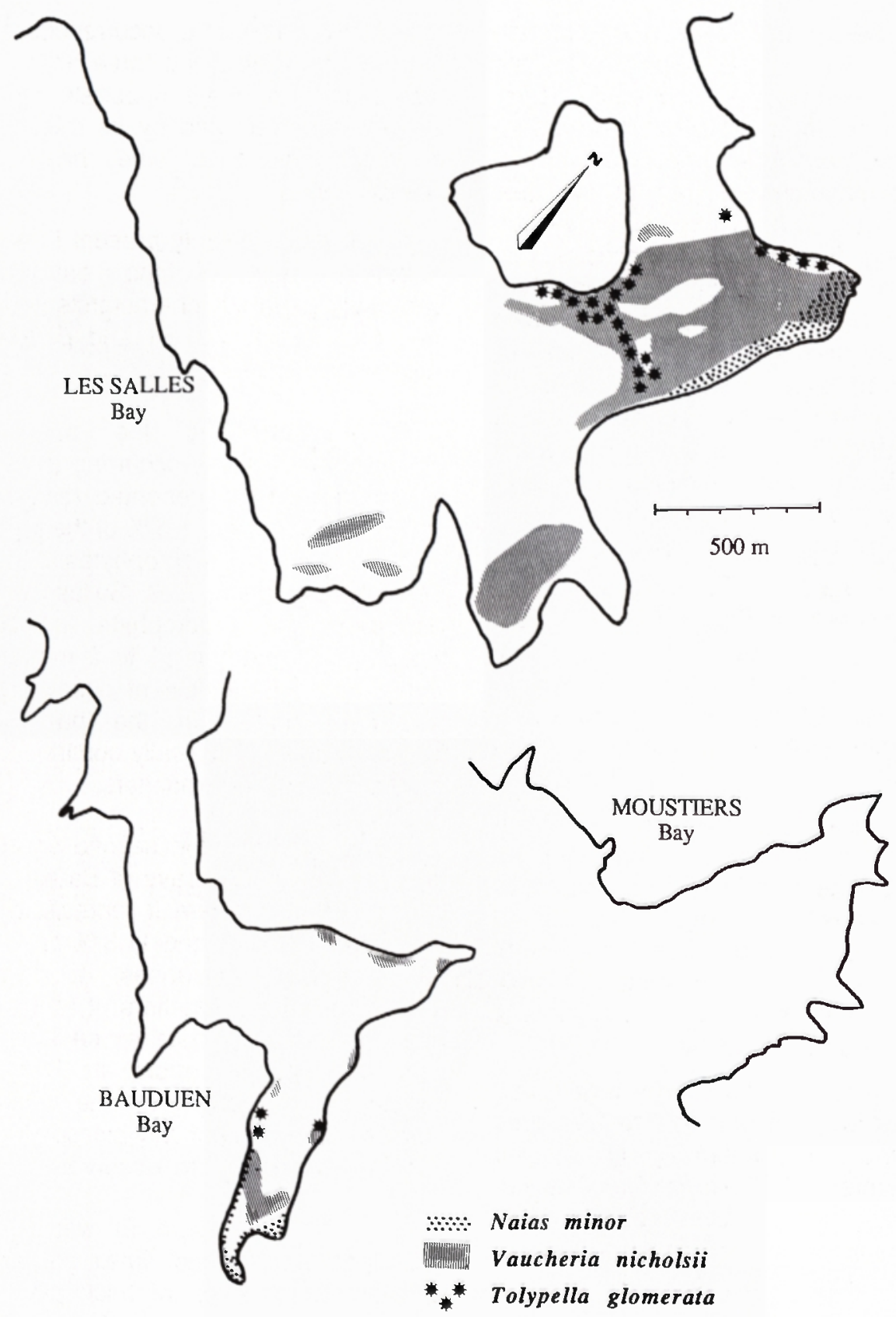

Fig. 3. - Distribition of Naias minor, Vaucheria nicholsii and Tolypella glomerata in the bays of Les Sailes, Bauduen and Moustiers in 1985. 
A. Vaquer et A. Champeau

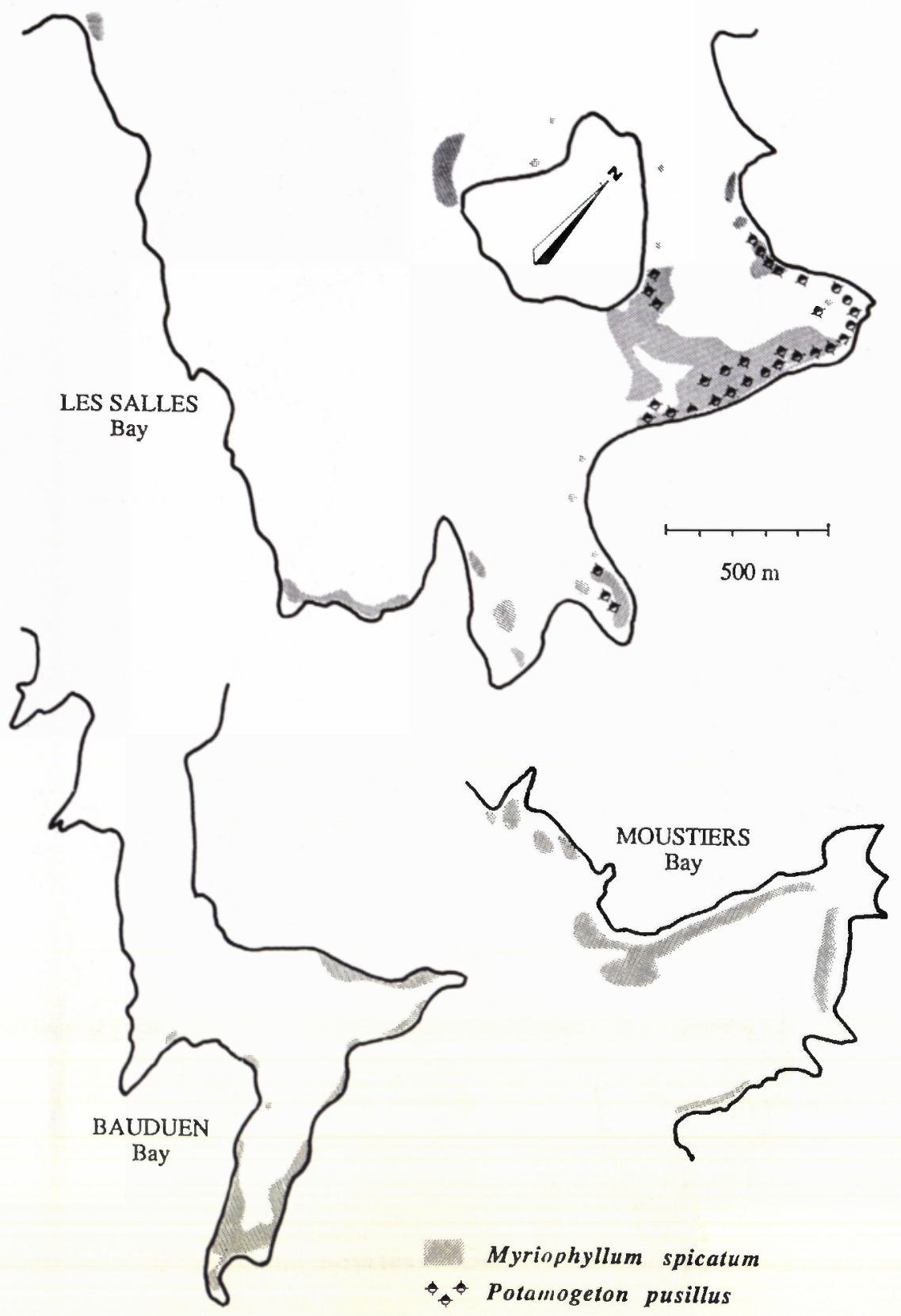

Fig. 4. - Distribution of Myrophyllum spicatum and Potamogeton pusillus in the bays of Les Salles, Bauduen and Moustiers in 1985. 
Macrophyte distribution in Lake Ste Croix

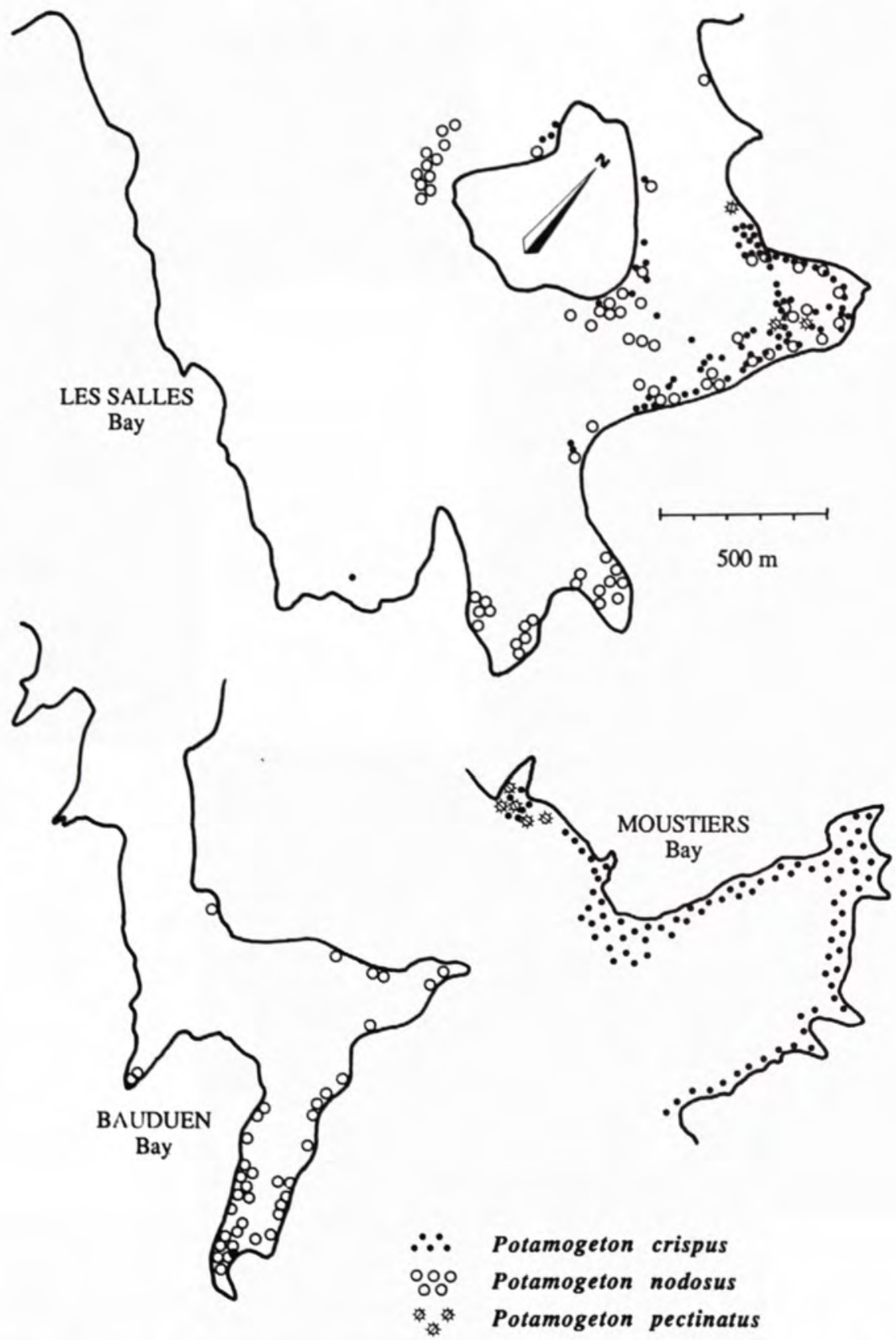

Fig. 5. - Distribution of Potamogeton nodosus, P. crispus and P. pectinatus in the bays of Les Salles, Bauduen and Moustiers in 1985. 
In fact, all the species were present in the bay of Les Salles but only $M$. spicatum was common and abundant in both the other bays and near the Ste Croix village. Specific richness was higher on the left shoreline of the lake and decreased from the upstream to the downstream part of the lake.

\section{Vertical distribution}

The examination of echosounding charts and grapnel sampling permitted to give accurate ranges of the depth of each macrophyte species. Maximum depths of $V$. Nicholsii, $M$. spicatum, $P$. crispus, $P$. nodosus, $P$. pectinatus, $P$. pusillus and $N$. minor are respectively $13 \mathrm{~m}, 9 \mathrm{~m}, 7 \mathrm{~m}$,
$7 \mathrm{~m}, 6 \mathrm{~m}, 5.3 \mathrm{~m}$, and $3 \mathrm{~m}$. So, submersed vegetation area is low limited to about a $10 \mathrm{~m}$ depth. $90 \%$ of the occurrences of $V$. nicholsii were nevertheless above $8.5 \mathrm{~m}$. Phanerogams grew in shallower zones : $90 \%$ of the occurrences of $M$. spicatum, $P$. crispus, $P$. nodosus and $P$. pectinatus were respectively observed at maximum depths of $6.2 \mathrm{~m}, 5.5 \mathrm{~m}, 5 \mathrm{~m}$ and $4.5 \mathrm{~m}$ (figure 6). Spring observations (in 1985) of $T$. glomerata indicate the maximum depth at 6 metres. The 0 $12 \mathrm{~m}$ water slice, submitted to frequent level fluctuations was practically not occupied except for terrestrial plants and scarce $N$. minor mats which where most of the time out of the water and completely dried-up during the summer of 1985.

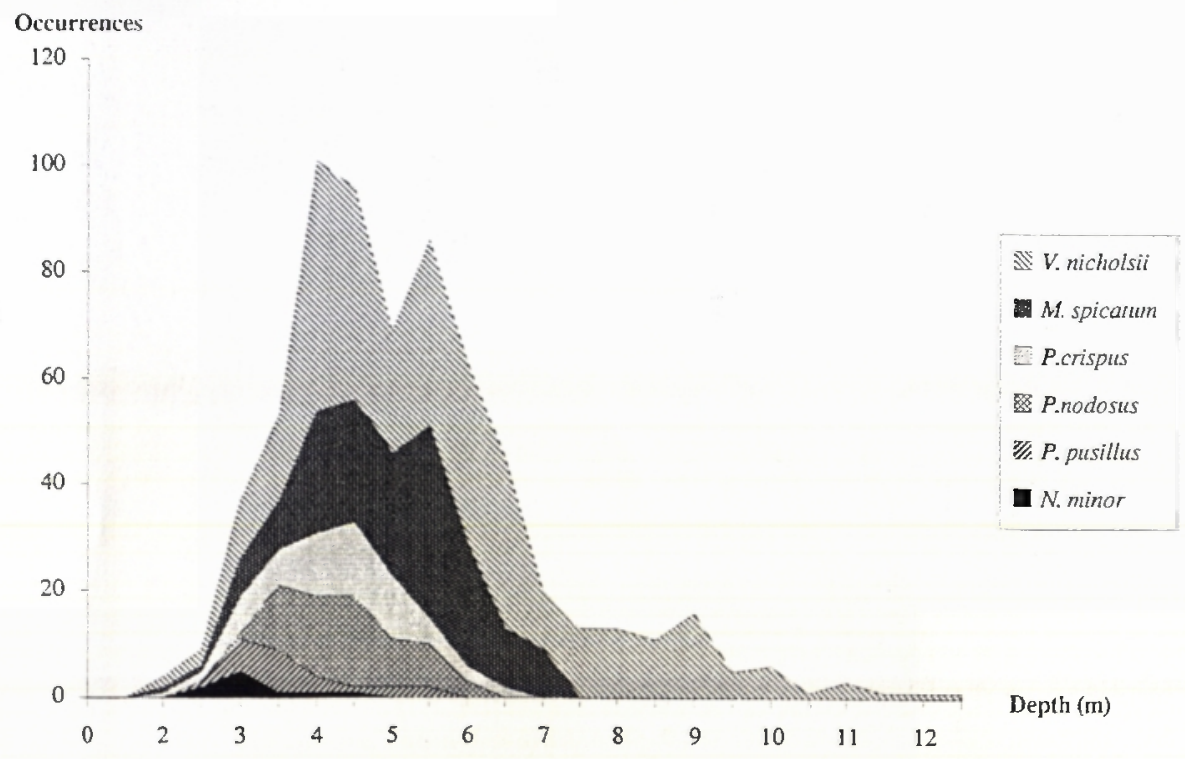

Fig. 6. - Vertical distribution of submersed macrophyte occurrences. Too scarce P. pectinatus and Tolypella glomerata lacking during summer observations are not represented. 
According to the whole lake's data, mean depths of all the macrophytes are very close, between $P$. pusillus $(3.5 \mathrm{~m})$ and Vaucheria. $(5.5 \mathrm{~m})$. However their comparison by t-Student test $(p<0.05)$ shows significant differences for all the species but the three Potamogeton which grew at the same depth range (tableau 2).

The comparisons of the mean depth of all the species in each bay by t-test and Mann-Whitney U-test are presented in table 3 and figure 7 . In the bay of Les Salles, mean depths between all the species are significantly different except the mean depths of $M$. spicatum, $P$. nodosus and $P$. crispus. On the contrary, in the bay of Bauduen only mean depth of $P$. nodosus is significantly different from the other species-ones while no difference between species appears in the bay of Moustiers. The mean depth of $M$. spicatum is greatest at Bauduen than in the other bays.

These differences between the three bays can be doubtless attributed to little mesological changes between each station as, for example, Secchi depth differences. So, during 85-86 annual cycle, the mean depth was $5.4 \mathrm{~m}$ in the central lake zone, $5.5 \mathrm{~m}$ in the bay of Bauduen, $4.3 \mathrm{~m}$ in the bay of Les Salles. It was only $3.3 \mathrm{~m}$ in the bay of Moustiers where the great water turbidity was linked to the

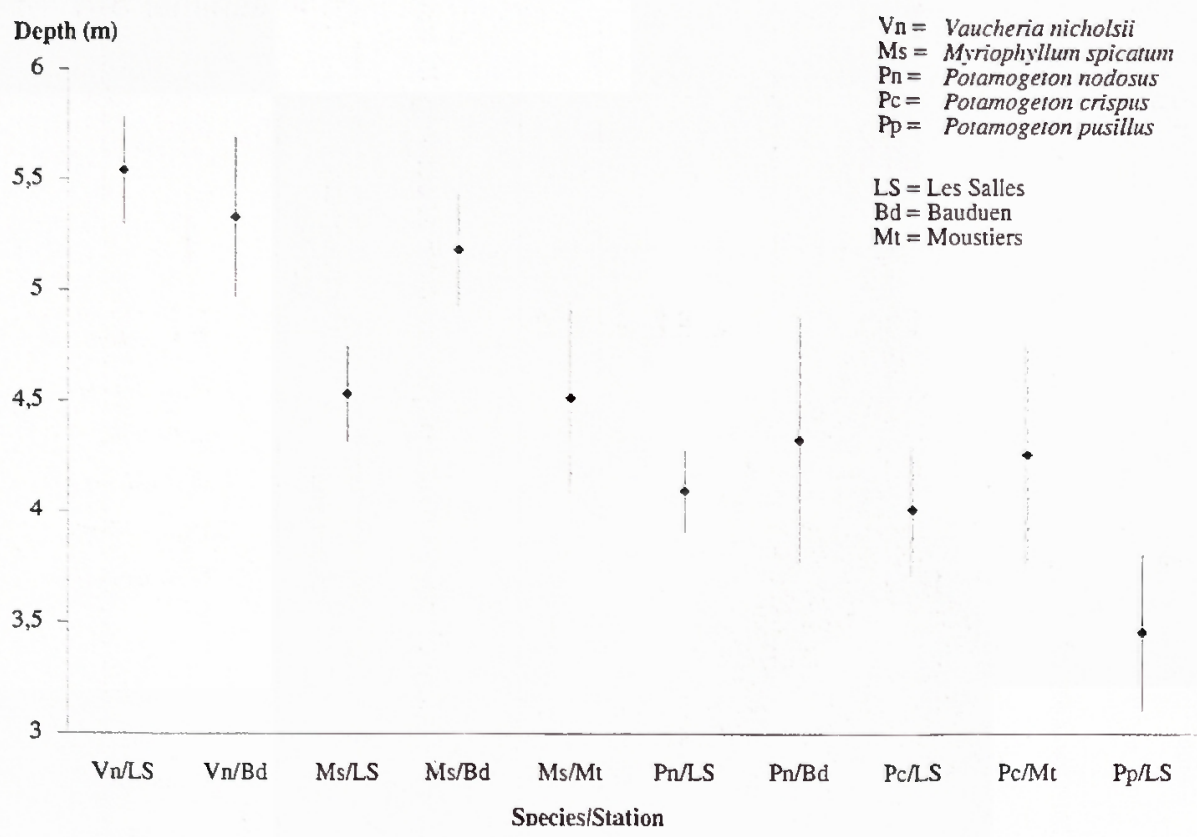

Fig. 7. - Mean depths and standard deviation error bars of the five main species of submersed macrophytes in the three bays. 

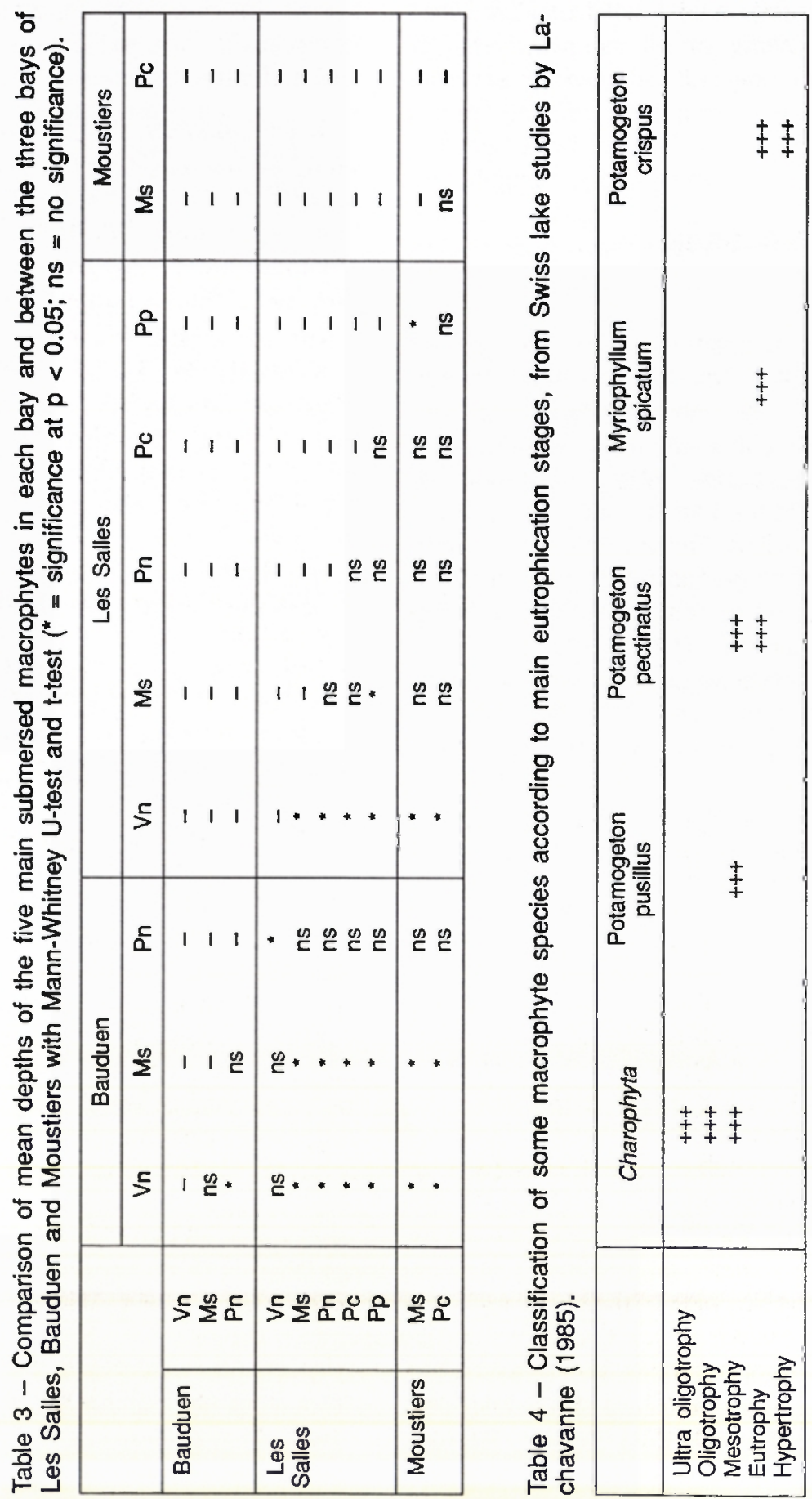
concentration of Mest from the River Maire inflow (on average $53.7 \mathrm{mg} . \mathrm{l}^{-1}$ ) against only $1.8 \mathrm{mg}^{-1} \mathrm{l}^{-1}$ in the whole lake.

\section{III - DISCUSSION}

Colonization by macrophytes of Lake Ste Croix is relatively recent. Before 1980 no vegetation was observed either in this lake nor in La Chaudanne Reservoir being located immediately upstream on the river Verdon. On the other hand, submersed vegetation was present in the downstream reservoirs of Quinson and Gréoux (Champeau and al., 1982) from which plants or pieces of plants could have been brought upstream by water pumpages of the Ste Croix factory. The first large macrophyte communities (Potamogeton sp., Naias sp. and Myriophyllum spicatum) were observed during 1982 and 1983 by Bressac \& Champeau (1985) and Chappaz et al. (1985).

The poor floristic list includes no particular species except macroalgae whose biological and ecological characteristics are little known. The simultaneous presence of the both algae is notable by the analogy with the association of Vaucheria dichotoma and Nitella flexilis pointed out by Casper and al. (1985) in the oligotrophic lake Stechlin. T. glomerata is known in alkaline to alkalinobriny temporary stations (Corillion, 1975). The littoral area of the lake being drained by water lowering during relative long periods can be compared to the temporary pieces of water drying up.

Each macrophyte species would characterize a different trophic level according to a classification (tableau 4) infered from Swiss lakes studied by Lachavanne (1985). Ozimek (1983) showed that M. spicatum is characteristic of eutrophic stations while Chara species are found in meso and oligotrophic stations. Ozimek \& Kowalczewski (1984) pointed out that a lake eutrophisation could be expressed by a Chara dominant to a Potamogeton - dominant vegetation transfer. In Lake Ste Croix, macrophytes are clustered in a few zones which are not representative of the oligo-mesotrophic lake status. The growth of the submersed vegetation in the bays and near the Ste Croix village is favoured by the nutrients present in the soil before its overlaying, but also by sewage supplies and by diffuse inflows from the nearby draining area being nutrient-enriched because of the important touristic flow around the lake from May to October. Diffuse nutrient inflows affect the whole littoral zone, while urban effluents are more localized and affect directly the three bays and near the shoal water at the base of the Ste Croix village.

The distribution of the main species in these different areas reflects their sensitivity or their tolerance to the water quality. The few sensitive $P$. crispus and $M$. spicatum are observed in all the three bays, particularly at the sewerage outflows of Bauduen, 
Ste Croix and Moustiers as being noted in Switzerland by Burgermeister \& Lachavanne $(1980,1984)$. In contrast, the very sensitive Characeae and $P$. pusillus only abundantly grew at Les Salles and were hardly found elsewhere. The dominant $P$. crispus and $M$. spicatum in the bay of Moustiers undoubtedly indicate a high pollution level owing to nutrient-rich inflow of the River Maire. Mean values of total nitrogen and total phosphorus are 730.5 and $169.7 \mu 1^{-1}$, i.e. respectively 3.2 and 8.5 times more than in the lake.

The horizontal distribution of the macrophytes is mainly due to the very sloping relief of the main part of littoral area of the lake : submersed vegetation was only noted in the three bays and on a few shoal. The bay banks are little sloping and are covered by a relatively thick layer of slimy substrate $(0.1$ to $1 \mathrm{~m})$ composed from genuine soils, often cultivated before water filling up (vineyards and meadows), or by sedimentation. On the other hand, the banks all around the lake are generally very sloping and composed from a slender genuine soil from which the slimest part has been carried by wave movements. This eroding action concerns the whole vegetation area because of the large range of the marling. So the soil along these sloping areas is actually constituted by pebbles and coarse gravels. Slimy substrates are favourable to the vegetable rooting and can provide them some nutrients. Their lack is a limiting factor of the productivity of the scarcely observed vegetation which cannot survive for a long time. The shoal near the Ste Croix village being colonized by a relatively thick vegetation is a particular case : the quite smooth bottom is mainly constituted by sand and fine gravels and nutrients are provided by the outflow of the village sewage.

Concerning vertical distribution, mean depth is $5.5 \mathrm{~m}$ for Vaucheria against $4.4 \mathrm{~m}$ for all other species. The maximal observed depth of Vaucheria and $M$. spicatum (respectively 13 and $9 \mathrm{~m}$ ) correspond to the maximal depth being known for the most aquatic macrophytes (on average $10 \mathrm{~m}$ for angiosperms and $12-14 \mathrm{~m}$ for lower plants, Pip \& Simmons, 1986). Concerning angiosperms, this depth would correspond to the euphotic depth ( $1-4 \%$ level of the transmitted light).

Most authors agree to attribute to light and correlatively to water transparency the main factors of the vertical distribution of macrophytes. Several predicting models of the maximal depth of the macrophyte distribution have been developped from bibliographic data or survey data of numerous lakes by using Secchi depth (Canfield et al., 1985; Chambers \& Kalff, 1985), mean attenuation coefficient (Vant et al., 1986) or downwelling light value (Duarte et al., 1986). The depth of the macrophytes distribution being predicted by using these different models with the mean values of Secchi depth $(5 / 4 \mathrm{~m})$ and mean attenuation coefficient $\left(0.32 \mathrm{~m}^{-}\right.$ $\left.{ }^{1}\right)$ being measured in Lake Ste Croix are relatively close to observed values. 
In the particular case of reservoirs, Rørslett (1985) suggests a predicting model of a characteristic depth («optimal depth") of macrophyte development being based on the mean annual regulation level. In Lake Ste Croix, the predicted characteristic depth $(4.5 \mathrm{~m})$ is very close to the observed mean depth of the macrophyte distribution $(4.9 \mathrm{~m})$. This observed depth can be considered as the characteristic depth according to the $90 \%$ occurrences between 2 and $8.5 \mathrm{~m}$.

All the models taking in account the Secchi depth or the light characteristics give generally a relative good assessment of the maximal depth of macrophyte colonization. The Rørslett's model, being based on mean annual marling level, gives a good indication for optimal development area. In the particular case of Lake Ste Croix, the unpredictable and irregular water level fluctuations are undoubtedly the first significant factor explaining the vertical macrophyte distribution. Substrate characteristics and nutrient supplies could explain the horizontal macrophyte distribution on a large scale in the lake. Smaller patches would result from colonization, interspecific competition and clone development, according to Carpenter \& Titus (1985). The former point is undoubtedly linked to a great ability of vegetative multiplication of all the species encountered, particularly the Potamogeton - ones, whose the great development of rhizomes and the production of various vegetative propagules give evidence.
Sloping relief, marling, low Secchi depth and/or attenuation coefficient are actually the main limiting factors of the spatial distribution of the submersed vegetation in Lake Ste Croix. But its too recent colonization cannot supply a sufficient retrospect to form an opinion on its evolution. Punctual observations during 1986 and 1987 have shown some significant changes of vegetation areas. For instance, $P$. crispus seemed to have the widest extent, $M$. spicatum became very scarce. This study suggests the importance of some mesological factors acting on the macrovegetation development and its implication on the ecological equilibrium of a reservoir. Considering the ability of plants to trap nutrient inflows in the nearly draining area, their conservation in moderate proportions may constitute an efficient protection against eutrophisation, as regards the water uses for domestic needs and leisures. Such reflections on the factors affecting the colonization and growth of macrophytes could be considered in the water regulation management of resenoirs.

\section{IV. - REFERENCES}

Anderson M.R. and Kalff J., 1986. Nutrient limitation of Myriophyllum spicatum growth in situ. Freshwater Biology, 16, 735-743.

Balls H., Moss B. and Irvine K., 1985. The effects of high nutrient loading on interactions between aquatic plants and phytoplankton. Verh. Internat. Verein. Limnol., 22, 2912-2915. 
Best E.P.H., De Vries D. and Rews A., 1984. The macrophytes in the Loosdrecht Lakes : a story of their decline in the course of eutrophication. Verh. Internat. Verein. Limnol., 22, 868-875.

Blake G. and Dubois J.P., 1982. Epuration des eaux: rôles des macrophytes aquatiques dans l'élimination des éléments minéraux, in Symoens J.J., Hooper S.S. \& Compère P., (ed.) : Studies on aquatic vascular plants. Roy. Bot. Soc. Belg., Brussels, p. 315-323.

Bressac Y. and Champeau A., 1985. Contribution à l'étude du réseau trophique des lacs de barrage : le zooplanction des retenues de Serre-Ponçon et Sainte Croix, in Gerdeaux D. \& Billard R. (ed.) : Gestion piscicole des lacs et retenues artificielles, INRA, Paris, p. 67-77.

Burgermeister G. and Lachavanne J.B., 1980. Les macrophytes du Pfäffikersee. Ber. Schweiz. Bot. Bes., 90 (3), 213-243.

Burgermeister G. and Lachavanne J.B., 1984. Caractérisation de la végétation macrophytique d'un lac hautement eutrophe: le Greifensee (Suisse). Schweiz. Z. Hydrol., 46(1), 117-138.

Canfield D.E., Langeland K.A., Linda S.B. and Haller W.T., 1985. Relations between water transparency and maximum depth of macrophyte colonization in lakes. J. Aquat. Plant Manage, 23, 25-28.

Carpenter S.R. and Titus J.E., 1985. Composition and spatial heterogeneity of submersed vegetation in a softwater lake in Wisconsin. Vegetatio, 57, 153 165.

Casper S.J., Kraush H.D. and Scheffler W., 1985. The plant communities. In Casper S.J. (ed.): Lake Stechlin. A temperate oligotrophic lake. $\mathrm{Dr}$. W. Junk Pub., Dordrecht 1985, p. 129 195.

Chambers P.A. and Kalff J., 1985. Depth distribution and biomass of submersed aquatic macrophyte communities in re- lation to Secchi depth. Can. J. Fish Aquat. Sci., 42 (4), 701-709.

Champeau A. (and Coll.), 1982. Les retenues hydro-électriques du Verdon : impact surla rivière, conséquences du marnage. Bull. Ecol., 13 (2), 203-239.

Chappaz R., Brun G. and Olivari G., 1985. La croissance du gardon dans la retenue de Sainte-Croix, in Gerbaux D. \& Billard R. (ed.): Gestion piscicole des lacs et retenues artificielles, INRA, Paris, p. 143-145.

Corillion R., 1975. Flore et végétation du massif armoricain. IV. Flore des Charophytes (Characées) du massif armoricain et des contrées voisines d'Europe occidentale. Jouve (ed.), Paris, p. 199-201.

Downing J.A. and Anderson M.R., 1985. Estimating the standing biomass of aquatic macrophytes. Can J. Fish. Aquatic Sci., 42, 1860-1869.

Duarte, C.M., 1987. Use of echosounder tracings to estimate the aboveground biomass of submerged plants in lakes. Can. J. Fish. Aquat. Sci., 44, 732-735.

Duarte C.M., Kalff J. and Peters R.H., 1986. Patterns in biomass and cover of aquatic macrophytes in lakes. Can J. Fish. Aquat. Sci., 43, 1900-1908.

Dubois J.P., Blake G., Gerbeaux P. and Jensen S., 1984. Methodology for the study of the distribution of aquatic vegetation in the French alpine lakes. Verh. Internat. Verein. Limnol., 22, 1036-1039.

Galanti G. and Guilizzoni P., 1985. Nutrient uptake by a floating-leaved aquatic plant (Trapa natans L.). Verh. Internat. Verein. Limnol., 22, 29432946.

Gillet C., 1985. Le déroulement de la fraie des principaux poissons lacustres, in Gerbeaux D. \& Billard R. (ed.) : Gestion piscicole des lacs et retenues artificielles, INRA, Paris, p. 167-185.

Grégoire A., 1982. Contribution à l'étude hydrobiologique d'une rivière aménagée: le Verdon. Les lacs de barrage 
et les tronçons de cours d'eau à débit régulé. Cahiers Lab. Hydrobiol. Montereau (EDF, France), $n^{6} 13,172$ p.

Hellquist C.B., 1980. Correlation of alkalinity and the distribution of Potamogeton in New England. Rhodora, 82 (830), 331-344.

Kadono Y., 1982. Distribution and habitat of japanese Potamogeton. Bot. Mag. (Tokyo), 95, 63-76.

Lachavanne J.B., 1985. The influence of accelerated eutrophication on the macrophytes of Swiss lakes: Abundance and distribution. Verh. Internat. Verein. Limnol., 22, 2950-2955.

Lachavanne J.B. and Wattenhofer R., 1975. Contribution à l'étude des macrophytes du Léman. Conservatoire botanique de Genève, $147 \mathrm{p}$.

Nichols S.A. and Shaw B.H., 1986. Ecological life histories of the three aquatic nuisance plants, Myriophyllum spicatum, Potamogeton crispus and Elodea canadensis. Hydrobiologia, 131, 3-21.

Nutall P.M., 1985. Uptake of phosphorus and nitrogen by Myriophyllum aquaticum (Velloza) Verd. growing in a wastewater treatment system. Aust. J. Mar. Freshw. Res., 36, 493-507.

Ozimek T., 1983. Biotic struclure and processes in the lake system of R. Jorka watershed (Masurian Lakeland, Poland). $X$. Biomass and distritution of submerged macrophytes. Ekol. Polska, 31 (3), 781-792.

Ozimek T. and Kowalczewski A., 1984. Long-term changes of the submerged macrophytes in eutrophic lake Mikolajskie (North Poland). Aquatic Botany, 19, 1-11.

Pip E. and Simmons K., 1986. Aquatic angiosperms at unusual depths in Skoal lake, Manitoba-Ontario. The Canadian Field Naturalist, 100, 354-358.
Ravera O., Garavaglia C. and Stella M., 1984. The importance of the macrophytes in two lakes with different trophic degree : lake Comabbio and lake Monate (Province of Varese, Northern Italy). Verh. Internat. Verein. Limnol., 22, 1119-1130.

Riber H.H., 1984. Phosphorus uptake from water by the macrophyte-epiphyte complex in a danish lake : relationship to plankton. Verh. Internat. Verein. Limnol., 22, 790-794.

Rørslett B., 1985. Regulation impact on submerged macrophytes in the oligotrophic lakes of Setesdal, South Norway. Verh. Internat. Limnol., 22, 2927-2936.

Schloesser D.W. and Manny B.A., 1982. Distribution and relative abundance of submersed aquatic macrophytes in the St-Clair-Detroit river ecosystem. Great Lakes Fishery Laboratory, 82 (7), 2-49.

Schloesser D.W. and Manny B.A. Distribution of submersed macrophytes in the St. Clair-Detroit River system. J. Freshwater Ecol., 3(4), 537-544.

Smith C.S. and Adams M.S., 1986. Phosphorus transfer from sediments by $M y$ riophyllum spicatum. Limnol. Oceanogr., 31(6), 1312-1321.

Stent C.J. and Hanlay S., 1985. A recording echosounder for assessing submerged aquatic plant populations in shallow lakes. Aquatic Botany, 21, 377394.

Vant W.N., Davies-Colley R.J., Clayton J.S. and Coffey B.T., 1986. Macrophyte depth limits in North Island (New Zealand) lakes of differing clarity Hydrobiologia, 137, 55-60.

Vaquer A. \& El Hafa M., 1991. Primary production of phytoplankton in an oligo-mesotrophic lake. Arch. Hydrobiol. 121 (2), 203-217. 